STUDIES IN RELIGIOUS FUNDAMENTALISM 
Also by Lionel Caplan

LAND AND SOCIAL CHANGE IN EAST NEPAL

ADMINISTRATION AND POLITICS IN A NEPALESE TOWN

CLASS AND CULTURE IN URBAN INDIA 


\section{Studies in Religious Fundamentalism}

\section{Edited by}

Lionel Caplan

Reader in Anthropology

School of Oriental and African Studies

University of London

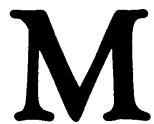

MACMILLAN

PRESS 
(C) Lionel Caplan 1987

Softcover reprint of the hardcover 1st edition 1987

All rights reserved. No reproduction, copy or transmission of this publication may be made without written permission.

No paragraph of this publication may be reproduced, copied or transmitted save with written permission or in accordance with the provisions of the Copyright Act 1956 (as amended) or under the terms of any licence permitting limited copying issued by the Copyright Licensing Agency, 7 Ridgmount Street, London WC1E 7AE.

Any person who does any unauthorised act in relation to this publication may be liable to criminal prosecution and civil claims for damages.

First published 1987

Published by

THE MACMILLAN PRESS LTD

Houndmills, Basingstoke, Hampshire RG21 2XS

and London

Companies and representatives

throughout the world

British Library Cataloguing in Publication Data

Studies in religious fundamentalism.

1. Religion

I. Caplan, Lionel

306'.6 GN470

ISBN 978-1-349-08832-4 ISBN 978-1-349-08830-0 (eBook)

DOI 10.1007/978-1-349-08830-0 


\section{Contents}

Preface

vii

Notes on the Contributors

1 Introduction

Lionel Caplan

2 The Quest for the Islamic State: Islamic

Fundamentalism in Egypt and Iran

Sami Zubaida

3 'Thank God we're Secular!' Aspects of

Fundamentalism in a Turkish Town

Richard Tapper and Nancy Tapper

4 A Case of Fundamentalism in West Africa: Wahabism in Bamako

Jean-Loup Amselle (translated by Donald Taylor)

5 Rethinking Fundamentalism: the Readjustment of Jewish Society in the Modern World

Jonathan Webber

6 The Khalsa Resurrected: Sikh Fundamentalism in the Punjab

Angela Dietrich

7 Incipient Fundamentalism: Religion and Politics among Sri Lankan Hindus in Britain

Donald Taylor

8 Fundamentalism as Counter-culture: Protestants in Urban South India

Lionel Caplan

9 The Moral Majority: the Politics of Fundamentalism in Secular Society

Steve Bruce

10 Fundamentalism and Modernity: the Restoration Movement in Britain

Andrew Walker

Author Index 


\section{Preface}

Fundamentalism has become an evocative notion in our time. But while those concerned with religious studies have considered fundamentalist tendencies in specific religious traditions, there has, to date, been little attempt to examine the phenomenon comparatively. The participants in this volume, though insistent on the importance of understanding the particular socio-cultural conditions in which fundamentalist ideas and behaviours emerge are, at the same time, inclined to explore the possibilities for more general insights. Two kinds of question, therefore, underlie our studies. First, what, in the complex historical context(s) discussed by each author, may be said to constitute 'religious fundamentalism'? Second, can we identify certain kinds of beliefs, discourses and activities which, though occurring in disparate cultural circumstances, enable us to speak of 'religious fundamentalism' as a viable category for cross-cultural analysis?

The origins of this book lie in an inter-collegiate seminar series organised by the Department of Anthropology at the School of Oriental and African Studies (University of London), which was held during the spring term, 1985. Six of the original participants appear in this volume, while three additional contributions were sought to provide a better regional and religious balance. The disciplinary emphasis is predominantly anthropological, though several of the participants identify themselves as sociologists. The chapters were all written for this symposium, with the exception of that by Jean-Loup Amselle, which appeared in a slightly different form, in French, in the Revue canadienne des études africaines, to which we are grateful for permission to reproduce the article.

It is hoped that readers who are regional specialists will excuse our decision, made in the interests both of consistency and of appealing to a wider readership, to omit all but the most basic diacritical marks when rendering foreign terms in the vernacular.

I am much indebted to the participants in this volume (as well as to those who are not in the collection but contributed to the original series) for their enthusiasm, perseverance and support in respect both of the initial seminars and the preparation of this publication. My greatest obligation is to Donald Taylor, who encouraged the idea of a collective exploration of religious fundamentalism, helped to recruit 
viii

several of the participants, offered a chapter on his own research, translated Amselle's article from the French, and in every way played a full and active part in the project.

Lionel CAPLAN 


\section{Notes on the Contributors}

Jean-Loup Amselle is Maître de Conférences at the Centre D'Études Africaines, École des Hautes Études en Sciences Sociales, Paris, where he teaches anthropology. He has conducted fieldwork in Mali, and is the author of Les Négociants de la Savanne, and other works.

Steve Bruce is Lecturer in Sociology in the Department of Social Studies, Queen's University, Belfast. He has studied conservative Protestantism in Ulster, Scotland and the USA, and has written several books, including Firm in the Faith: the Survival of Conservative Protestantism.

Lionel Caplan is Reader in Anthropology with reference to South Asia at the School of Oriental and African Studies, London. His previous research in the Himalayas gave rise to several monographs, including Land and Social Change in East Nepal. He has also produced a number of essays on his recent research among South Indian Christians.

Angela Dietrich completed her MA in Ethnology, Sociology and Indian History at the University of Heidelberg. She is currently a $\mathrm{PhD}$ student at Konstanz University, specialising in the sociology of Sikhism, in connection with which she recently spent 14 months in the Punjab, and published a paper on Sikh demands for autonomy.

Nancy Tapper is part-time Lecturer in the Department of the History and Philosophy of Religion at King's College, London, where she teaches the anthropology of religion. She has done fieldwork in Iran, Afghanistan and, most recently, Turkey, and has written numerous articles on the anthropology of women and religion in the Muslim Middle East.

Richard Tapper is Reader in Anthropology with reference to the Middle East at the School of Oriental and African Studies. The primary focus of his research has been on ritual and tribalism in Afghanistan, Iran and Turkey. He is the author of Pasture and Politics, and has edited The Conflict of Tribe and State in Iran and Afghanistan. 
Donald Taylor is Senior Lecturer in Religious Studies at Middlesex Polytechnic, London. He holds a doctorate in theology from Oxford, and is currently completing a thesis on the anthropology of religion at the School of Oriental and African Studies, based on research among Sri Lankan Tamil Hindu migrants in Britain. He has published several papers on this work.

Andrew Walker is Honorary Research Fellow at King's College, London, and Director of the C. S. Lewis Centre for the Study of Religion and Modernity. His main research interests are in the sociology of charismatic movements and in philosophical and theological anthropology. He is the author of Restoring the Kingdom: the Radical Christianity of the House Church Movement and other publications.

Jonathan Webber is Junior Research Fellow at Linacre College, Oxford, and Fellow in Social Studies at the Oxford Centre for Postgraduate Hebrew Studies. He is senior editor of JASO, the Journal of the Anthropological Society of Oxford. He has done research in Jerusalem and has written a number of articles on modern Jewish society.

Sami Zubaida is Senior Lecturer in Sociology at Birkbeck College, London. He has recently completed a research project on the Islamicisation of government in Iran, and has published several papers on religion and Islamic movements in that country as well as in the Arab world. 